synthetic substance without the two methyl groups on the benzene ring was completely inactive in this dose. The synthetic substance combines with the protein of the 'yellow ferment' of Warburg, prepared according to the method of Theorell, yielding a catalytically active compound, thus behaving exactly like lactoflavin. The optical rotation in alkaline solution of the two substances is the same. In order to decide definitely whether the two compounds are identical in every respect, Kuhn intends to prepare compounds containing the ribose and xylose radical, instead of arabinose, for comparison.

\section{Irrigation in India}

THe report on "Irrigation in India in 1931-32" (Delhi : Department of Industries and Labour) shows that the total irrigated area in British India in that year fell slightly below thirty million acres, of which more than half was in the Punjab and the Madras Presidency. In the whole area, the figures represent slightly more than 12 per cent of the area sown, rising to 34 per cent in the Punjab and 93 per cent in Sind. Among the largest new irrigation works in progress is the construction of a dam at Mettur on the Cauvery to store flood waters. About half this work was completed by the end of the year. The works in connexion with the new Lloyd barrage at Sukkur in Sind are approaching completion.

\section{Research in Dairying}

THE annual report for 1933 of the National Institute for Research in Dairying, University of Reading, contains a summary of the work done during the year in the various departments, and brief abstracts of papers published from the Institute. Reference is made to the death of the first director, Dr. Stenhouse Williams, in whose memory a new library building has been erected. Attention is also directed to the financial stringency from which the Institute is suffering, and which will necessitate the abandonment of valuable work now being conducted in the Physiology Department and the Nutritional Laboratory unless additional funds are forthcoming within the next few months.

\section{Exhibition of Architecture}

AN exhibition of an interesting character has recently been opened at the new premises of the Royal Institute of British Architects, 66 Portland Place, London, W.1. Here is to be seen a collection of more than 1,200 large photographs of buildings and many models showing recent developments in architecture throughout the world. It has taken two years to bring together this international collection, which is well displayed and is divided into subjects such as public buildings, hospitals, schools, houses, which enables the visitor to compare the designs of leading architects in different countries side by side in a manner which is seldom possible. The exhibition does not deal with planning or construction, but for those interested in these matters there are a few sets of drawings and particulars showing all the stages through which a project must pass before a building can reach completion; the extent of this detailed work will probably be a surprise to the layman. The exhibition is open to the public without charge from 10 to 6 until January 5 .

\section{American Association for the Advancement of Science}

THE ninety-fifth meeting of the American Association for the Advancement of Science will be held at Pittsburgh commencing on December 27. On December 31, the retiring president, Dr. Henry Norris Russell, will deliver an address entitled "The Atmospheres of the Planets". Among the general addresses to be delivered are: Prof. E. A. Horton, "Homo sapiens, Whence and Whither"; Prof. Arthur B. Lamb, "Crystallogenetic Adsorbents"; Dr. A. Franklin Shull, "Weismann and Hæckel : One Hundred Years" ; Prof. H. H. Newman, "Twins reared apart and the Nature-Nurture Problem"; Dr. Mark H. Liddell, "The Auditory Spectrum". Prof. Albert Einstein will deliver the Josiah Willard Gibbs lecture of the American Mathematical Society on December 28. On December 30, there will be a symposium on the relation between science, especially scientific organisations and institutions, and the Press. Speakers will represent the universities, technical and medical schools, the National Association of Science Writers, Science Service, the Associated Press, the Hearst Service and representative newspapers. Further information about the meeting can be obtained from Dr. Henry B. Ward, American Association for the Advancement of Science, Smithsonian Institution Building, Washington, D.C.

\section{Announcements}

SIR IsIDORE SALMON, chairman and managing director of Messrs. J. Lyons and Co., Ltd., has been elected president of the Decimal Association, in succession to Lord Hirst.

THE Karl Sudhoff medal has been awarded by the German Society of the History of Medicine, Natural Sciences and Technique to Prof. T. Györy, professor of the history of medicine in the University of Budapest.

THe annual meeting in 1935 of the British Medical Association will be held at Melbourne on September 11-13, under the presidency of Sir Richard Stawell, consulting physician to the Melbourne Hospital.

Applications are invited for the following appointments, on or before the dates mentioned:-A lecturer in electrical engineering at the North Staffordshire Technical College, Stoke-on-Trent-The Clerk to the Governors, Education Office, Town Hall, Hanley, Stoke-on-Trent (Dec. 31). An assistant in the Technological Department of tho Royal Scottish Museum, Edinburgh, 1-The Director (Jan. 12). A principal of the Northern Counties' Training College of Cookery and Domestic Science, Newcastleupon-Tyne-The Secretary (Jan. 14). An assistant in natural history in the University of AberdeenThe Secretary (Jan. 20). A Dunville professor of physiology and a J. C. White professor of biochemistry in the Queen's University of BelfastThe Secretary (Feb. 28). A chemist in the Admiralty Chemical Pool-The Secretary of the Admiralty (C.E. Branch), Whitehall, London, S.W.1. 